\title{
Growth and Body Development of Oreochromis niloticus (Linnaeus, 1758) Fattened in Floating Cages Based on Commercial Feed in Benin
}

\author{
Géoffroy Olayèmi Edea (Corresponding Author)
}

Department of Science and Animal Production, Laboratory of Biotechnology and Animal Improvement, Biomedical Institute of Applied Science, Doctoral College of Life and Earth Sciences, Faculty of Science and Technology, University of Abomey-Calavi, 01 P.O. Box 526, Cotonou, Benin. E-mail: edeaolayemi@gmail.com; Phone: +229 94764901 / 66691457

\section{Lambert Cloud Hinvi}

Department of Science and Animal Production, Laboratory of Hydrology and Aquaculture (LHA), Faculty of Agricultural Sciences, University of Abomey-Calavi (UAC), Benin E-mail: copprapp@yahoo.fr; lambert.hinvi@fsa.uac.bj; Phone: +22966262803

\section{Youssouf Abou}

Department of Zoology, Laboratory of Ecology and Management of Aquatic Ecosystems, Faculty of Science and Technology, University of Abomey-Calavi, 01 P.O. Box 526, Benin

E-mail: y_abou@yahoo.com; Phone: +229 95422775 / 65954666

\section{Armand Bienvenu Gbangboche}

Department of Science and Animal Production, Laboratory of Biotechnology and Animal Improvement, Biomedical Institute of Applied Science, Faculty of Agricultural Sciences - University of Abomey-Calavi, Cotonou, Benin

College of Management and Exploitation of Livestock Systems -National University of Agriculture - 01 P.O. Box 43 Campus of Ketou - Republic of Benin. E-mail: gbangboche_ab@hotmail.com; Phone: +229 96114727

Received: August 13, 2019 Accepted: September 23, 2019

doi:10.5296/jbls.v11i1.15259 URL: https://doi.org/10.5296/jbls.v11i1.15259 


\section{Abstract}

This work evaluates the growth and body development of Oreochromis niloticus in floating cages in the Toho Lake of Benin. Thus, 6000 juvenile monosex male with an average initial weight of $8.87 \pm 4.89 \mathrm{~g}$ and average initial total length of $7.87 \pm 1.43 \mathrm{~cm}$ were randomly distributed in two floating cages $\left(5 \times 5 \times 2.5 \mathrm{~m}^{3}\right)$ at the stocking density of $3000 \mathrm{fish} / \mathrm{cage}$. The fish were hand-fed to apparent satiation, three times daily, using 45-32\% crude protein commercial pelleted floating feed Skretting ${ }^{\circledR}$. The physico-chemical parameters of lake water recorded every 72 hours during the experiment were within the suitable ranges for fish culture and were as follows: temperature $\left(27.78 \pm 0.41{ }^{\circ} \mathrm{C}\right), \mathrm{pH}(7.55 \pm 0.22)$, dissolved oxygen $(4.03 \pm 0.96 \mathrm{mg} / \mathrm{l})$, ammonium $(0.31 \pm 0.18 \mathrm{mg} / \mathrm{l})$, nitrite $(0.29 \pm 0.07 \mathrm{mg} / \mathrm{l})$ and nitrate $(0.27 \pm 0.12 \mathrm{mg} / \mathrm{l})$. The variables studied at the end of the 215 days of rearing were as follows: final mean total length $(26.61 \pm 2.99 \mathrm{~cm})$, final mean standard length $(22.40 \pm$ $2.74 \mathrm{~cm})$, final mean predorsal length $(6.93 \pm 0.94 \mathrm{~cm})$, final mean head length $(3.45 \pm 0.58$ $\mathrm{cm})$, final mean dorsal fin base length $(13.55 \pm 2.96 \mathrm{~cm})$, final mean inter-orbital width $(2.97$ $\pm 0.37 \mathrm{~cm})$, final mean body height $(8.57 \pm 1.56 \mathrm{~cm})$ and final mean caudal peduncle height $(3.27 \pm 0.39 \mathrm{~cm})$. The zootechnical growth parameters evaluated were as follows: survival rate $(91.5 \%)$, final mean body weight $(402.18 \pm 137.05 \mathrm{~g})$, average daily weight gain $(1.83 \pm$ $0.08 \mathrm{~g})$, specific growth rate $(0.77 \pm 0.03 \% /$ day $)$, feed conversion ratio $(1.74 \pm 0.09 \%)$ and protein efficiency ratio $(1.62 \pm 0.06)$. These results compared to the literature indicate interesting growth and body development and it would be important to promote in-cage farming of Oreochromis niloticus.

Keywords: Oreochromis niloticus, breeding, growth, cage, commercial feed

\section{Introduction}

There are about 80 species of tilapia, mostly from the African continent and, beyond the Suez Canal, from the region of Israel and Jordan among which, only some of the Oreochromis genus have the qualities required for aquaculture (Legros, 1995). The zootechnical characteristics of Oreochromis niloticus or tilapia (the ease with which they can breed, their relatively fast growth, their high tolerance to extreme rearing and harsh environmental conditions (high stocking density, low oxygen levels, etc.), resistance to handling, resistance to disease, good consumer acceptance) make this species, the most interesting and the basis of the freshwater fish farming in the intertropical belt of the globe (Legros, 1995; Arrignon, 1998; Lazard, 2007). According to its diet, Oreochromis niloticus can reach a market size of $400 \mathrm{~g}$ in 8 months (Lazard, 2007) and its commercial production generally requires the use of male monosex populations because they grow about 30\% faster than females (Macintosh et al., 1985; Smith and Phelps, 2001; Ridha, 2011). In view of all the above, one of the possibilities for optimizing the production of Oreochromis niloticus or Nile tilapia could be its cage culture as it presents more advantages over other farming methods, such as culture ponds or raceways (Care, 2000; Gupta and Acosta, 2004). Cage culture is commonly used in water bodies that cannot be drained, such as lakes, estuaries, reservoirs or coastal marsh areas. Cage culture practices have numerous advantages over other culture systems. By integrating the cage culture system into the aquatic ecosystem the carrying capacity per unit area is optimized because the free flow of 
current brings in water and removes metabolic wastes, excess feed and faecal matter (Beveridge, 1984). In addition, cage-culturing requires low investment costs, easy management, easy and low cost of harvesting, opportunities for close observation of feeding and health status of fish (McGinty and Rakocy, 2005). Cages can be floating surface or standing surface cages, and the material by which they are constructed should be durable, lightweight, and cheap, such as a galvanized and plastic coated welded wire mesh, plastic netting and nylon mesh (Fitzsimmons, 2004). According to Beveridge (1996), cage aquaculture is an old practice. It dates back to early $10^{\text {th }}$ century when Chinese fishermen used to fatten fry in cage made with bamboo stick. Similar farming practices have been reported in both freshwater and marine environments, including open ocean, estuaries, lakes, reservoirs, ponds and river (Eng and Tech, 2002). However, the knowledge of the behavior of cultured species is crucial for the construction of an appropriate cage (McGinty and Rakocy, 2005). In the case of Oreochromis niloticus, it is less active and sometimes territorial in habitat, the shape of the cage does not affect its mobility, however, for easy assemblage and management rectangular cage is appropriate (Fitzisimmons, 2004). However, this farming practice is still embryonic in Benin, where national aquaculture production is still struggling to meet the ever-increasing demand. The present study aims to evaluate the growth performance and body development of Oreochromis niloticus, in floating cage based on imported commercial feed, with a view to translating the results into a diffusion technological package.

\section{Materials and Methods}

\subsection{Study Area, Animal Descriptions, Study Design and Assessment of Growth and Body Development}

The trial was conducted for a 215 days period (from September 27, 2015 to May 18, 2016) at the Aquaculture Incubation Centre of Toho, a private fish farm located in Pahou in the municipality of Ouidah $\left(6^{\circ} 22^{\prime} 00^{\prime \prime} \mathrm{NORTH}, 2^{\circ} 05^{\prime} 00^{\prime \prime} \mathrm{EAST}\right)$. A total of $6000 \mathrm{O}$. niloticus juvenile monosex male (Initial mean body weight IMBW: $8.87 \pm 4.89 \mathrm{~g}$; initial mean total length IMTL: $7.87 \pm 1.43 \mathrm{~cm}$ ) were collected from the Aquaculture Research and Incubation Center of Benin, weighed and stocked in two (02) square floating net cages (size of each cage: $5 \mathrm{~m} \times 5 \mathrm{~m} \times 2.5 \mathrm{~m}$ ) (Figure 1) in the Toho Lake at a stocking density of $3000 \mathrm{fish} / \mathrm{cage}$. This stocking density used, i.e. $48 \mathrm{fish} / \mathrm{m}^{3}$, is close to the optimal value of $50 \mathrm{fish} / \mathrm{m}^{3} \mathrm{recommended}$ by Moniruzzaman et al. (2015).

The fish were hand-fed to apparent satiation, three times daily at $9.00 \mathrm{am}, 1.00 \mathrm{pm}$ and $5.00 \mathrm{pm}$, using 45-32\% crude protein commercial pelleted floating feed Skretting®. The fish progressively received $2 \mathrm{~mm}, 3 \mathrm{~mm}$ and $4.5 \mathrm{~mm}$ pellets from the beginning to the end of the trial. Water quality parameters such as temperature, $\mathrm{pH}$, dissolved oxygen, ammonium, nitrite and nitrate were monitored at 72-hour intervals throughout the experimental period. Temperature and $\mathrm{pH}$ were recorded using a portable digital thermo- $\mathrm{pH}$ meter ( $\mathrm{pHep} \mathrm{3);} \mathrm{test} \mathrm{kits} \mathrm{were} \mathrm{used} \mathrm{for} \mathrm{the}$ other parameters, namely Vunique V-Color 9750 for ammonium, Vunique V-Color 9780 for dissolved oxygen and API FRESHWATER MASTER TEST KIT for nitrite and nitrate.

Sampling was done at the end of the experimental period to access the growth performance and body development of the fish. Then, random samples of 1300 fish from each cage were caught. 


\section{Macrothink}

The measurable morphometric characters of the fish as described by Stiassny et al. (2007), recorded at the beginning and the end of the trial were as follows: Total Body Length (TL), Standard Length (SL), Predorsal Length (PL), Head Length (HL), Dorsal Fin Base Length (DFBL), Interorbital Width (IOW), Body Height (BH) and Caudal Peduncle Height (CPH) (Figure 2). The Body Weight (BW) was also recorded during the trial. Weight was measured with a digital electronic scale (SH \& A: SHS: SUPER HYBRID SENSOR; max range: $2200 \mathrm{~g}$; accuracy: $0.01 \mathrm{~g}$ ) for small and medium sized fish and another digital electronic scale (UWE; max capacity: $30 \mathrm{~kg}$; accuracy: $5 \mathrm{~g}$ ) to weigh large specimens. The morphometric parameters of the fish were measured using an ichtyometer (Total length: $1 \mathrm{~m}$; graduated in $\mathrm{cm}$ ) for the large fish, and a Vernier caliper (graduated in $\mathrm{cm}$ ) used for small specimens. To determine the growth response of the experimental fish, several parameters were calculated (Table 3): Final Mean Body Weight (FMBW, g), Average Daily Weight Gain (ADWG, g), Specific Growth Rate (SGR, \%/day), Feed Conversion Ratio (FCR) and Protein Efficiency Ratio (PER). The Survival Rate (\%) of the fish was also evaluated at the end of the experiment.

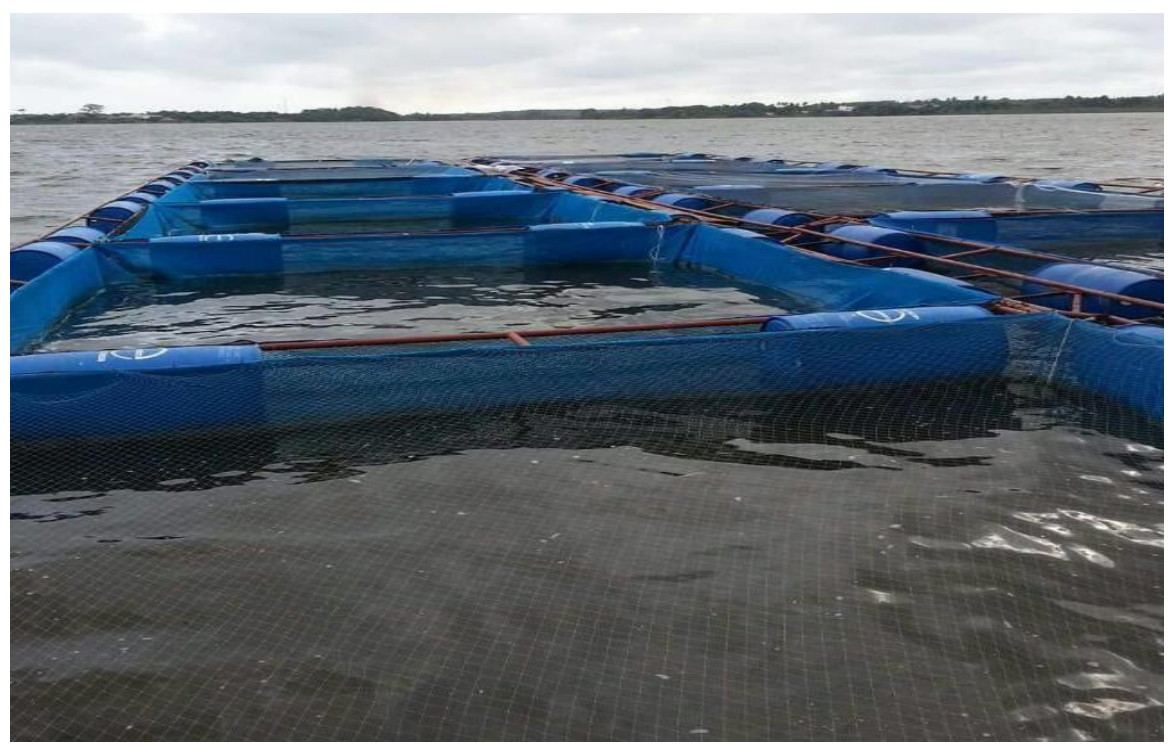

Figure 1. O. niloticus breeding device: floating cages in Toho Lake of Benin

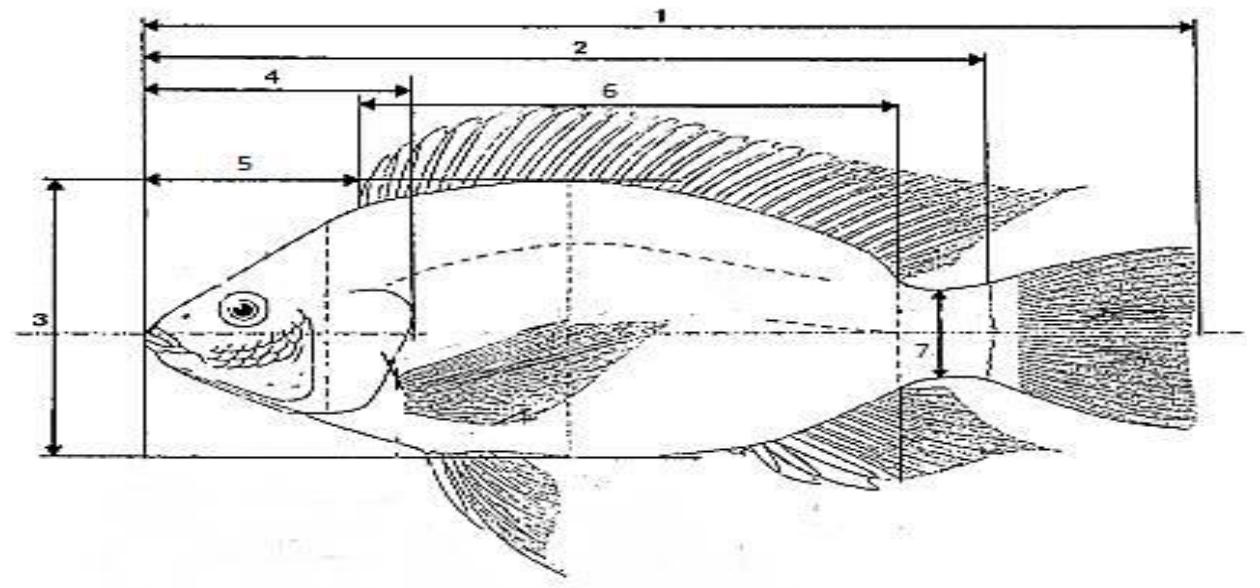

Figure 2. Principal measurements taken on O. niloticus (Fermon, 2011) 


\section{Macrothink}

Journal of Biology and Life Science

ISSN 2157-6076

2020, Vol. 11, No. 1

Legend: 1- Total length (TL), 2- Standard length (SL), 3- Body height (BH), 4- Head length (HL), Interorbital width (IOW), 5- Predorsal length (PL), 6- Dorsal fin base length (DFBL), 7- Caudal peduncle height $(\mathrm{CPH})$.

\subsection{Statistical Analysis}

Data relating to growth and body development parameters (TL, SL, BH, HL, IOW, PL, DFBL, $\mathrm{CPH}$ and $\mathrm{BW})$ and also physico-chemical parameters of the water (Temperature $\left({ }^{\circ} \mathrm{C}\right) ; \mathrm{pH} ; \mathrm{O}_{2}$ (mg/l); $\mathrm{NH}_{3} / \mathrm{NH}_{4}(\mathrm{mg} / \mathrm{l}) ; \mathrm{NO}_{2}(\mathrm{mg} / \mathrm{l}) ; \mathrm{NO}_{3}(\mathrm{mg} / \mathrm{l})$ ) were subjected to a descriptive statistical analysis, using Statistical Analysis System (SAS, 2008). The different rates such as SR, SGR, FCR, PER and the ADWG were calculated from the raw data.

Data on the total body length (TL) and body weight (BW) were recorded from each sampled fish. The parameters $a$ and $b$ of the length-weight relationship were estimated by logarithmic transformation of the equation $B W=a \times T L^{b}$, in which $B W$ is the body weight $(\mathrm{g}) ; T L$ is the total body length (cm); $a$ is the intercept; and $b$ is the slope. Length-weight relationships were used to provide the condition of fish and determine whether growth is isometric $(b=3)$ or allometric (negative allometric: $b<3$, or positive allometric: $b>3$ ). When $b=3$, there is a good distribution in the body development of the fish (Pauly, 1983). However, $b<3$ indicates $a$ better growth in length than in weight, while $b>3$ means a better growth in weight than in length (Micha, 1973; Ricker, 1973; Weatherley and Gill, 1987).

\section{Results}

\subsection{Water Quality}

Table 1. Water quality parameters recorded in male monosex O. niloticus floating cages during the study period (values are expressed as mean $\pm \mathrm{SE}$ ).

\begin{tabular}{lr}
\hline $\begin{array}{l}\text { Physico-chemical } \\
\text { parameters }\end{array}$ & Mean $\pm \mathrm{SE}$ \\
\hline Temperature $\left({ }^{\circ} \mathrm{C}\right)$ & $27.78 \pm 0.41$ \\
$\mathrm{pH}$ & $7.55 \pm 0.22$ \\
$\mathrm{O}_{2}(\mathrm{mg} / \mathrm{l})$ & $4.03 \pm 0.96$ \\
$\mathrm{NH}_{3}-\mathrm{N}(\mathrm{mg} / \mathrm{l})$ & $0.31 \pm 0.18$ \\
$\mathrm{NO}_{2}(\mathrm{mg} / \mathrm{l})$ & $0.29 \pm 0.07$ \\
$\mathrm{NO}_{3}(\mathrm{mg} / \mathrm{l})$ & $0.27 \pm 0.12$ \\
\hline
\end{tabular}

Data in Table 1 represents the mean values of the rearing water quality parameters. The results showed that physico-chemical parameters remained within the optimum gaps for tilapias, evidenced by the survival rate of $91.5 \%$ obtained. 
3.2 Morphometric Parameters and Body Weight of Fish

Table 2. Morphometric parameters and body weight of male monosex $O$. niloticus at stocking and $215^{\text {th }}$ day of breeding in floating cages (values are expressed as mean $\pm \mathrm{SE}$ ).

Morphometric parameters $(\mathrm{cm})$ and Body weight $(\mathrm{g})$

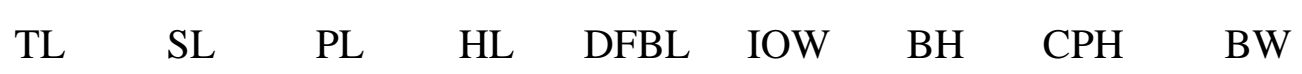

\section{Phases}

\begin{tabular}{lccccccccc} 
At & 7.87 & 6.41 & 1.96 & 0.99 & 3.51 & 0.79 & 2.13 & 0.85 & 8.87 \\
stocking & \pm 1.43 & \pm 1.23 & \pm 0.62 & \pm 0.35 & \pm 0.74 & \pm 0.21 & \pm 0.47 & \pm 0.20 & \pm 4.89 \\
& & & & & & & & & \\
At & 26.61 & 22.40 & 6.93 & 3.45 & 13.55 & 2.97 & 8.57 & 3.27 & 402.18 \\
harvesting & \pm 2.99 & \pm 2.74 & \pm 0.94 & \pm 0.58 & \pm 2.96 & \pm 0.37 & \pm 1.56 & \pm 0.39 & \pm 137.05 \\
\hline
\end{tabular}

The mean values of morphometric parameters of fish (TL, SL, PL, HL, DFBL, IOW, BH, CPH) and body weight (BW) obtained at the end of the trial period are presented in Table2. The results revealed good adaptation and growth of Oreochromis niloticus in cages. 


\subsection{Zootechnical Parameters of Fish}

Table 3. Zootechnical parameters of monosex male O. niloticus after 215 days breeding period in floating cages in Toho Lake of Benin (values are expressed as mean $\pm \mathrm{SE}$ )

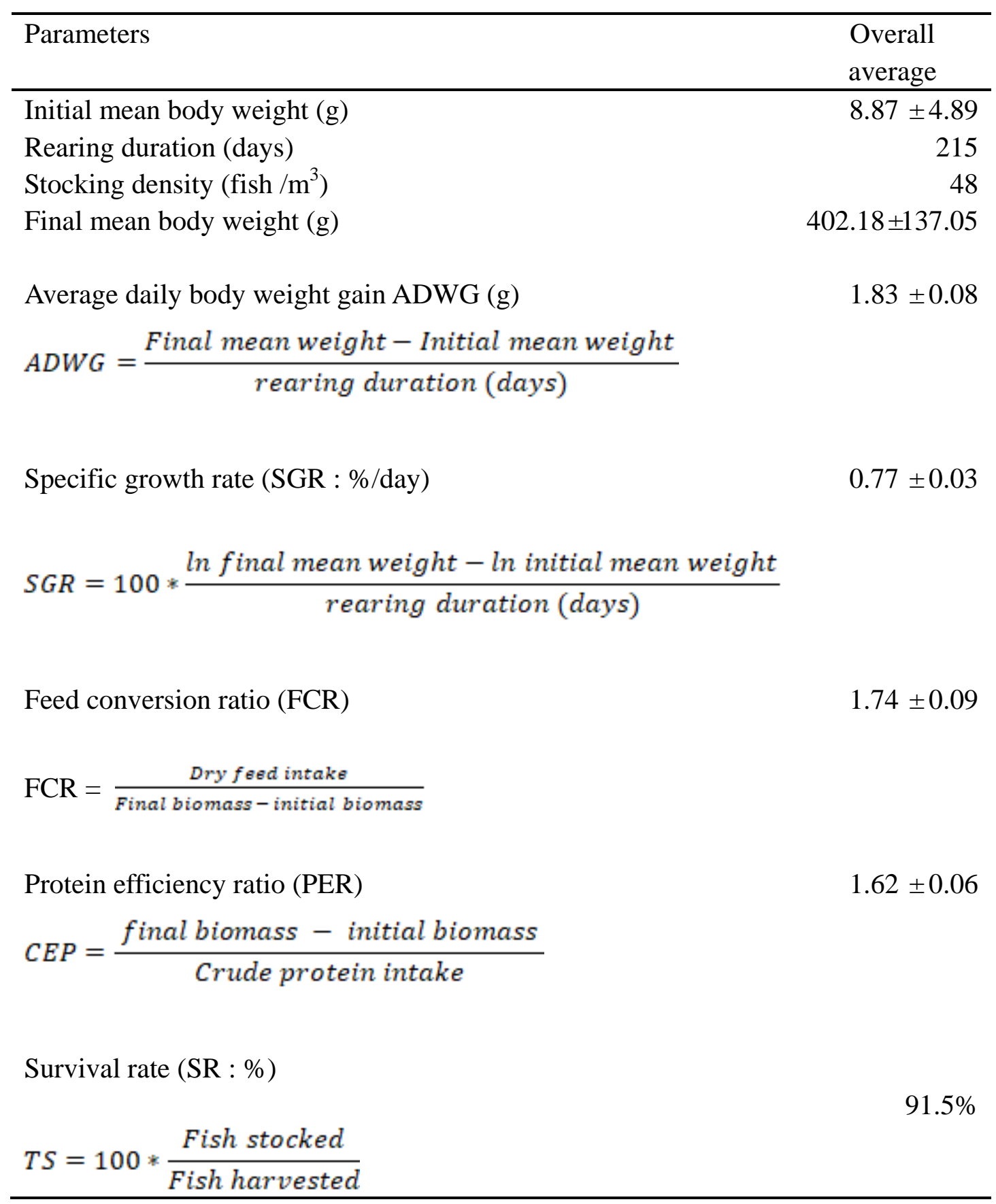

Table 3 presents the zootechnical parameters of the fish. The results revealed good feed use, protein efficiency, specific growth rate and encouraging ADWG. 
3.4 Length-Weight Relationship

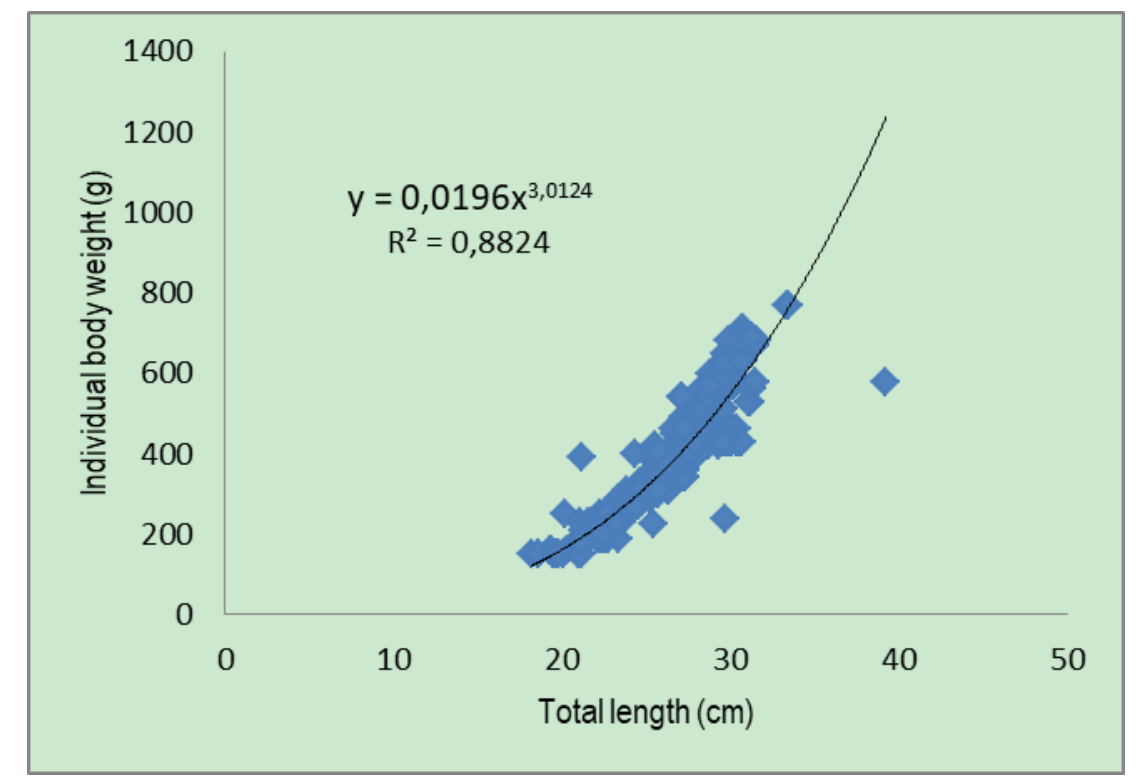

Figure 3. Length-weight relationship of growing-finishing monosex male O. niloticus in cage- farming system

The length-weight relationship equation of male monosex $O$. niloticus at the end of the trial was as follows: $B W=0.019 \times T L^{3.0124},\left(\mathrm{R}^{2}=0.8824\right)$ (Figure 3$)$. The value of slope $\mathrm{b}$ in the equation was equal to 3.0124 . This value being relatively equal to 3 , then revealed an isometric growth of the fish; indicate a good distribution in the growth and body development.

\section{Discussion}

\subsection{Physico-Chemical Parameters of Water}

The water quality parameters monitored throughout this study meet the standards required for the breeding of the Nile tilapia Oreochromis niloticus such as: $22-29{ }^{\circ} \mathrm{C}$ for temperature (Sarig, 1969; Morgan, 1972; Caulton, 1982; Mires, 1995); 6.5-9 for $\mathrm{pH}$ (Hepher and Pruginin, 1981); dissolved oxygen content of the water $>3 \mathrm{mg} / \mathrm{l}$ (Ross, 2000); nitrite content < $0.3 \mathrm{mg} / \mathrm{l}$ (Boyd, 1998); 0.2 - $10 \mathrm{mg} / \mathrm{l}$ for nitrate (Boyd, 1998). The importance of water quality in aquaculture was highlighted by some authors (Arulampalam et al., 1998; Thirupathaiah et al., 2012) and would justify a major role in the well-being of the fish, as evidenced by the analysis of the breeding water quality in this study.

\subsection{Zootechnical Parameters}

Generally, fish growth is dependent on several factors which, according to their nature, can be grouped as follows: farming environment, farming management and intrinsic factors related to the animal. Environmental factors include the availability of food resources in the environment and the physico-chemical quality of the species habitat (temperature, dissolved oxygen concentration, luminosity, etc.) (Ezenwaji and Ikusemiju, 1981; De Merona et al., 1988; Panfili et al., 2002; Fontaine and Le Bail, 2004), the device or medium of breeding (Coche, 1978). For 
example, cage culture of tilapia species such as O. niloticus (Coche, 1978; Cavailles et al., 1981) and Sarotherodon melanotheron Rüppell 1852 (Ouattara et al., 2003) improves production and the rearing of mixed-sex populations without recruitment and stunting problems, which are important constraints in traditional culture systems. Concerning the factors related to fish farming management, they include: composition and quality of feeds (Moraes et al., 2009 ; Ashraf et al., 2011; Slawski et al., 2011), stocking density (Araujo et al., 2010), feeding methods (Ridha, 2011), feeding frequency (Yager and Summerfelt, 1993; Davies et al., 2006; Garcia and Villarroel, 2009), availability of food resources in ponds or cages, and feeding rate (Diana et al., 1991; Ng et al., 2000; Mihelakakis et al., 2002; Kestemont et al., 2003), fish rearing duration (Fermon, 2011; Silva et al., 2015). According to Shugunan (1997), higher stocking density reduces the growth and survival rates during fish culture. Increasing stocking density results in stress (Leatherland and Cho, 1985) which leads to enhanced energy requirements causing reduced growth and food utilization (Hengsawat et al., 1997). On the other hand, competition for food is a limiting factor for growth of young fish. Competition and aggressive behaviour increase under situations of food shortage (Symnons, 1971; Essa, 1996). Finally, the intrinsic factors related to the animal include: strain (Dey and Gupta, 2000), genetic background of the fish (Conover, 1992), species (Amoussou et al., 2016), difference between the initial weights (Abdel-Hakim et al., 2008), sexual dimorphism (Bwanika et al., 2007; Ridha, 2011; Wadgy et al., 2011; Chakraborty and Benerjee, 2012). It was reported that the discrepancy in the growth performance between male and female tilapia is multi-factorial. It is believed to be related to channeling of energy from somatic growth toward egg production in females (Rakocy and McGinty, 1989; Baroiller and Borel, 1997), anabolic effects of the male sex steroids and growth hormones, genes linked to sex determination and greatly reduced feeding activity of brooding females (Toguyeni et al., 1997a; Toguyeni et al., 2002).

However, the growth influencing factors considered in this study are: feed content and quality, feeding management, stocking density, rearing device, trial duration, rearing water quality; feed intake level of fish, sexual dimorphism, difference in initial weights of fish at stocking, difference in final weights of fish at harvesting, fish strain, genetic background of fish.

\subsubsection{Final Mean Body Weight}

O. niloticus juvenile monosex at the end of the experiment presented a final mean body weight of $402.18 \pm 137.05 \mathrm{~g}$, higher than the values of $255.53 \pm 16.36 ; 227.24 \pm 15.05 ; 206.36 \pm 14.06$ and $172.62 \pm 14.89 \mathrm{~g}$ reported for similar populations reared for 120 days and fed with a commercial pelleted floating feed (29\% protein) at 3-5\% of body weight in cages at densities of 50, 75, 100 and $125 \mathrm{fish} / \mathrm{m}^{3}$ respectively (Moniruzzaman et al., 2015). The disparity of results could be attribute to the difference in the protein content of fish feed, the stocking density, and the trial duration. It is also observed that an increase in stocking density results in lower body weight of fish. On the other hand, lower final mean body weight values of $200.08 \pm 0.8$ and $123.4 \pm 0.76 \mathrm{~g}$ were also reported respectively for juvenile monosex male and mixed sex populations of the same species after 6 months of pond culture $\left(3 \mathrm{fish} / \mathrm{m}^{2}\right)$ using $28 \%$ crude protein diet twice daily at $4 \%$ body weight (Githukia et al., 2015). An average weight of 217.90 $\mathrm{g}$ has also been reported for $O$. niloticus grown in floating cages $\left(135 \mathrm{fish} / \mathrm{m}^{3}\right)$ on the Niger 
River after 225 days of rearing, based on a diet containing $31 \%$ of proteins, $1 / 3$ of which are of animal origin (Lazard and Legendre, 1994). Disparity between authors' results may be due to variation in diet protein quality and content; difference in stocking density, rearing device, trial duration; and sex-specific difference. Indeed, number of study has reported a faster growth rate in male monosex when compared to mixed sex O. niloticus (Mair et al., 1995; Dan and Little, 2000; Little et al., 2003; Chakraborty et al., 2011). Due to their sexual dimorphism, males grow significantly larger and are more uniform in size than females (Ponzoni et al., 2005; Nguyen et al., 2007). Dagne et al. (2013) highlighted that lack of energy expenditure in egg production and mouth brooding by females and lower energy expenditure on courtship are some of the reasons behind faster growth rate in male monosex tilapia. According to de Oliveira et al. (2012), stocking density is the concentration that fish are stocked into a system. It directly influences fish growth, feed utilization, survival and fish health (Lovell, 1989; Wocher et al., 2011). Rearing fish at inappropriate stocking densities may impair growth and reduce immune competence due to factors such as social interactions and deterioration of water quality, that negatively affect the feed conversion efficiency and growth of the fish (Ellis et al., 2002).

\subsubsection{Average Daily Weight Gain}

The ADWG of $O$. niloticus monosex in this study after 215 days trial at a stocking density of 48 $\mathrm{fish} / \mathrm{m}^{3}$ is of $1.83 \pm 0.08 \mathrm{~g}$. It is greater than the value of $1.05 \mathrm{~g}$ reported for juvenile male monosex after 6 months of pond culture ( $3 \mathrm{fish} / \mathrm{m}^{2}$ ) using $28 \%$ crude protein diet twice daily at $4 \%$ body weight (Githukia et al., 2015). On the other hand, an ADWG of $0.62 \mathrm{~g}$ was presented by a mixed sex juvenile of the same species, reared in ponds (Githukia et al., 2015). The influence of density is also highlighted because Moniruzzaman et al. (2015) under cage-culturing system reported ADWG values of $2.01 \mathrm{~g} ; 1.76 ; 1.59$ and $1.31 \mathrm{~g}$ for $O$. niloticus juvenile male reared at densities of $50 ; 75 ; 100$ and $125 \mathrm{fish} / \mathrm{m}^{3}$ respectively. With higher density, authors obtained lower ADWG compared to our study. This result corroborates the observations of Lovell (1989) and Wocher et al. (2011) who reported that stocking density directly influences fish growth and feed utilization. Rearing fish at inappropriate stocking densities may impair its growth (Ellis et al., 2002). Only all males bred at a stocking density of $50 \mathrm{fish} / \mathrm{m}^{3}$ performed relatively better than that of our study. This disparity could be due to difference in fish strain (GIFT strain) and initial mean weight of fish $(15.20 \pm 0.15 \mathrm{~g})$ used by Moniruzzaman et al. (2015), compared to that of our study (initial mean weight: $8.87 \pm 4.89$ g). Lower ADWG $(0.81 \mathrm{~g})$ than that of our study was reported by Lazard and Legendre (1994), for $O$. niloticus reared in cage at a density of $135 \mathrm{fish} / \mathrm{m}^{3}$. Nevertheless, higher growth has been reported for male monosex of Nile tilapia raised at a density of $83 \mathrm{fish} / \mathrm{m}^{3}$ in circular cages (Silva et al., 2015). Using males and females of a genetically improved strain (GIFT) of $O$. niloticus cultured in recirculating tanks, the values of $3.19 \pm 0.08 \mathrm{~g}$ and $1.93 \pm 0.04 \mathrm{~g}$ were respectively reported while males and females of unimproved strains exhibited ADWG of 2.16 \pm 0.22 and $1.18 \pm 0.08 \mathrm{~g}$ respectively in the same rearing system (Ridha, 2011). It is understood that fish strain has significant influence on its growth.

\subsubsection{Specific Growth Rate}

The SGR obtained in this study $(0.77 \pm 0.03 \% /$ day $)$ is lower compared to the values of $1.83 \pm$ 
$0.15 \%$ /day and $1.47 \pm 0.18 \%$ /day reported respectively for pond raised $O$. niloticus monosex male and mixed sex (Githukia et al., 2015). The SGR of this study is also lower than the rates of 2.35; 2.25; 2.17 and 2.02\%/day reported by Moniruzzaman et al. (2015) in floating cage culture for the monosex male of the same species at the stocking densities of 50; 75; 100 and $125 \mathrm{fish} / \mathrm{m}^{3}$ respectively. This disparity could be attributed to difference in stocking density, fish strain, rearing device, and fish feeding management. In recirculating tanks culture system, genetically improved strain (GIFT) of $O$. niloticus showed higher SGR (male:

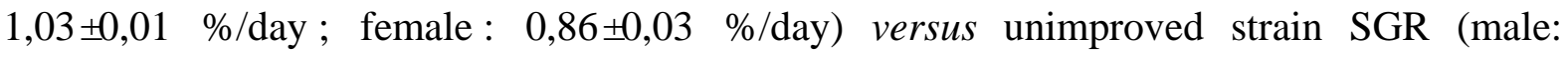
$0,86 \pm 0,03 \% /$ day; female: $0,72 \pm 0,04 \% /$ day) (Ridha, 2011). All monosex male Nile tilapia in this study showed better SGR than unimproved female strain. This could be attributed to fish strain and sexual dimorphism of the fish.

\subsubsection{Feed Conversion Ratio}

FCR is considered as an important indicator of the quality of fish feed and lower FCR indicates better utilization of the fish feed (Mugo-Bundi et al., 2013). This study showed lower FCR (1.74 \pm 0.09$)$ compared to $1.81 ; 1.92 ; 1.97$, and 2.05 reported by Moniruzzaman et al. (2015) for juvenile monosex male tilapia raised in floating cages at densities of 50;75; 100 and 125 fish $/ \mathrm{m}^{3}$. This performance could be due to the quality of the feed used in this study and the feeding management. On the other hand, the FCR of juvenile monosex tilapia in this study is respectively lower than that of $1.92 \pm 0.03$ reported for mixed sex tilapia in pond culture (Githukia et al., 2015), and 3.0 reported by Lazard and Legendre (1994) in floating cage culture in Niger. According to Ellis et al. (2002) rearing fish at inappropriate stocking densities may impair growth and reduce immune competence due to factors such as social interactions and deterioration of water quality, that negatively affect the feed conversion efficiency and growth of the fish.

\subsubsection{Protein Efficiency Ratio}

Protein is the main constituent of the fish body thus sufficient dietary supply is needed for optimum growth (Pillay, 1990). Protein efficiency ratio (PER) is based on the weight gain of a test subject divided by its intake of a particular food protein during the test period (Buamah and Singsen, 1975). According to Bahnasawy et al. (2009), fish growth is significantly affected by diet protein level. The PER of this study $(1.62 \pm 0.06)$ is in the interval from 1.25 to 1.98 reported by Khattab et al. (2000) for Nile tilapia in pond culture. It is also between the range of 1.34 to 1.85 reported for $O$. niloticus reared in recirculating water system, using feed containing respectively $35 \%$ and $20 \%$ crude protein content at a stocking density of $60 \mathrm{fish} / \mathrm{m}^{3}$ (Bahnasawy et al., 2009). Ahmad et al. (2004) found PER of 1.92; 1.58 and 1.98 for tilapia fingerlings $(20.3 \mathrm{~g}$ ) reared in concrete tanks using a recirculating system and a diet containing $25 ; 35$ and $45 \%$ crude protein respectively. The disparity between results could be due to difference in: the diet protein content, feed quality, feeding management, the feed intake level of fish, the final weight of fish, the breeding water source and the breeding device indirectly. Indeed, Ghozlan et al. (2018) reported a significant influence of water sources on PER. According to the authors, PER is significantly improved with each increase in pond sizes and decrease in stocking density. Ellis et al. (2002) also reported that rearing fish at inappropriate 
stocking density may lead to water quality deterioration and affect negatively the feed conversion efficiency. However, cage farming in a water body offers the advantage of automatic or natural water renewal without any kind of energy.

\subsubsection{Survival Rate}

Male monosex tilapia in this study showed a good SR value of $91.5 \%$. In comparison to the literature which highlights the effect of density on survival, higher SR values (96.8 and 92.6\%) were reported by Moniruzzaman et al. (2015) for monosex tilapia reared under cage culture system at densities of 50 and 75 fish $/ \mathrm{m}^{3}$ respectively. On the other hand, respectively similar $(91.2 \%)$ and lower $(83.1 \%)$ survival rate were reported by the same authors for monosex tilapia bred at stocking densities of 100 and $125 \mathrm{fish} / \mathrm{m}^{3}$ under the same culture system. In addition, a similar survival rate $(90.70 \%)$ to that of our study was reported for $O$. niloticus monosex reared in floating cage at a stocking density of $135 \mathrm{fish} / \mathrm{m}^{3}$ (Lazard and Legendre, 1994). That performance, despite the high density applied by these authors could be favored mainly by the higher initial mean weight $(35.70 \mathrm{~g})$ of the fish.

\subsection{Body Development of Fish}

At the end of the study, the fish showed significant increase in the recorded eight morphometric parameters. Indeed, the length gain $(\mathrm{cm})$ obtained was of 18.74 for TL; 15.99 for SL; 4.97 for PL; 2.46 for HL; 10.04 for DFBL; 2.18 for IOW; 6.44 for BH and 2.42 for CPH. The daily body development $(\mathrm{cm})$ of this species is therefore of 0.087 for TL; 0.074 for SL; 0.023 for PL; 0.011 for HL; 0.047 for DFBL; 0.010 for IOW; 0.030 for $\mathrm{BH}$ and 0.011 for $\mathrm{CPH}$.

The comparative growth performance of male monosex and mixed sex Nile tilapia (Oreochromis niloticus) (Initial mean weight: $12.2 \mathrm{~g}$; initial mean TL: $7.6 \mathrm{~cm}$ ) reared in earthen ponds was performed by Githukia et al. (2015). Daily length gain values of $0.08 \mathrm{~cm}$ and 0.06 $\mathrm{cm}$ were showed respectively by the monosex male and mixed sex at a stocking density of 3 fish $/ \mathrm{m}^{2}$. A relatively better result $(0.087 \mathrm{~cm})$ was obtained in this study after 215 days of trial using floating cages at a stocking density of $48 \mathrm{fish} / \mathrm{m}^{3}$ or $120 \mathrm{fish} / \mathrm{m}^{2}$. These performances could be attributed to the difference between rearing devices, duration of breeding, crude protein content of feed and feeding management.

Kebede (2011) studied for 6 months the effect of food quality ( 22 to $24.28 \% \mathrm{CP}$ ) on the growth performance of mixed sex $O$ niloticus raised in floating cages. The characteristics of the fish at the beginning of rearing were of $42.80-43.51 \mathrm{~g}$ for weight, $11.93-12.5 \mathrm{~cm}$ for TL and the stocking density was $100 \mathrm{fish} / \mathrm{m}^{3}$. The daily length gain $(0.087 \mathrm{~cm}$ for $\mathrm{TL})$ recorded in the males of $O$. niloticus in our study was higher, compared to the values reported for mixed sex cohorts ranging from 0.026 to $0.034 \mathrm{~cm} /$ day. This difference observed in body development could be attributed to the high stocking density, sex dimorphism, rearing duration, and lower crude protein content of the diet used by this author.

The effect of stocking density on growth of monosex tilapia (O. niloticus) (initial mean weight: $15.20 \mathrm{~g}$; initial mean total length: $9.16 \mathrm{~cm}$ ) under cage culture in Kaptai Lake of Bangladesh was performed by Moniruzzaman et al. (2015). Daily length gain values of $0.116 ; 0.106 ; 0.10$ and $0.078 \mathrm{~cm}$ were reported after 120 days of rearing, respectively at stocking densities of 50; 
$75 ; 100$ and $125 \mathrm{fish} / \mathrm{m}^{3}$. In spite of the lower crude protein content of the pelleted feed (28.76\%) distributed, O. niloticus showed better growth compared to the one obtained in our study except for the cohort reared at the density of $125 \mathrm{fish} / \mathrm{m}^{3}$. This high performance could mainly be attributed to the genetically improved strain used by these authors, and also to the difference in the initial mean body weight of the fish. At the end of 180 days of rearing at similar stocking density (49 fish $/ \mathrm{m}^{3}$ ) in floating cages, O. mossambicus fed on natural resources showed a daily length gain $(0.084 \mathrm{~cm})$ similar to that obtained in our study, while higher growth $(0.103 \mathrm{~cm})$ has been reported for the same species when fed with commercial pellet (Balkhande, 2019). The effect of stocking density on the production of Nile tilapia ( $O$. niloticus) (Akosombo strain) (initial mean body weight: 2.09 - $2.15 \mathrm{~g}$; initial standard length: $3.97-4.09 \mathrm{~cm}$ ) was also studied in floating cages on the Volta Lake by Asase (2013) at the stocking densities of 50;100 and $150 \mathrm{fish} / \mathrm{m}^{3}$. At the end of 177 days of rearing test, the daily length gain values for SL showed by the fish in increasing order of the densities were as follows: $0.075 ; 0.072$ and $0.069 \mathrm{~cm}$. Except for the fish raised at a density of $150 \mathrm{fish} / \mathrm{m}^{3}$, the results showed by $O$. niloticus are similar to those obtained at the end of our study. However, a decline in body development is observed with an increase in density.

\subsection{Length-Weight Relationship}

The length-weight relationship of $O$. niloticus monosex was established, based on the equation $B W=0.0196 T L^{3.0124}\left(\mathrm{R}^{2}=0.8824\right)$ (Figure 2). Indeed, the value of the coefficient $b(3.0124)$ is not significantly different from 3 , thus revealing an isometric growth of the fish considering the scale of Ricker (1973). There is, therefore, a good distribution in length and weight of the body development. This observation is in line with that reported by Silva et al. (2015) in juvenile monosex male Nile tilapia (initial mean weight $=28.6 \pm 4.16 \mathrm{~g}$ ) raised in circular cages $\left(12 \mathrm{~m}^{3}\right.$ each). The good distribution of growth in this population could be attributed to: the absence of females, whose early maturity and reproduction usually contribute to overpopulation and stunting, leading therefore to poor quality and small size fish (Lazard, 2009).

\section{Conclusion}

The results of the present study revealed good adaptation and good growth performance and body development of male monosex Oreochromis niloticus in-cage farming system. This breeding structure has enabled an automatic and natural renewal of water, thus maintaining a suitable quality for fish growth. In addition, the stocking density adopted (50 fish $/ \mathrm{m}^{3}$ ) in accordance with the recommendations of the literature has contributed to obtaining a good fish survival and a good use of the feed distributed. All these factors allowed for a better expression of the performances of the species. Promoting the growing-finishing of male monosex Nile tilapia in cage culture system could therefore be recommended to farmers to improve their production so that they could make more effective contribution to achieving food security and improving their profits. 


\section{Acknowledgement}

The authors wish to acknowledge Mr. Gilbert Cossi Tonon, Mr. Hermes Tonon, and Mr. Christian Guidibi of Tonon Foundation for their assistance. They would also like to thank the staff of Benin Aquaculture Incubation and Research Centre and Toho Aquaculture Incubation Centre for their collaboration.

\section{References}

Abdel-Hakim, N. F., Ammar, A. A., \& Salah, A. A. (2008). Effect of initial stocking size and production cycle on growth performance of monosex tilapia reared in earthen ponds. $8^{\text {th }}$ International Symposium on Tilapia in Aquaculture, 255-269.

Ahmad, M. H., Abdel-Tawwab, M., \& Khattab, Y. (2004). Effect of dietary protein levels on growth performance and protein utilization in Nile tilapia (Oreochromis niloticus) with different initial body weight. Sixth international symposium on tilapia in aquaculture, Manila, Philippine, 249-263.

Amoussou, T. O., Toguyeni, A., Imorou, T. I., Chikou, A., \& Youssao, A. K. I. (2016). Caractéristiques biologiques et zootechniques des tilapias africains Oreochromis niloticus (Linnaeus, 1758) et Sarotherodon melanotheron Rüppell, 1852 : une revue. Int. J. Biol. Chem. Sci. 10(4).1869-1887. https://doi.org/10.4314/ijbcs.v10i4.35

Araujo, G. S., Rodrigues, J. A. G., Da Silva, J. W. A., \& Farias, W. R. L. (2010). Cultivo da tilápia do Nilo em tanques-rede circulares em diferentes densidades de estocagem. Bioscience Journal, 26, 428-434.

Arrignon, J. (1988). Aménagement piscicole des eaux douces 5éme éditions, Lavoisier, Paris. p. 589.

Arulampalam, P., Yusoff, F. M., Law, A. T., \& Rao, P. S. S. (1998). Water quality and bacterial populations in a tropical marine cage culture farm. Aquaculture Research, 29, 617-624. https://doi.org/10.1046/j.1365-2109.1998.00248.x

Asase, A. (2013). Effect of stocking density on the production of Nile tilapia (Oreochromis niloticus) in floating net cages on Volta Lake. A thesis submitted in partial fulfillment of the requirement for the Award of MPHIL Fisheries Science Degree. University of Ghana, Legon. p.111.

Ashraf, M. Zafar, A., Rauf, A., Mehboob, S., \& Qureshi, N. A. (2011). Nutritional values of wild and cultivated silver carp (Hypophthalmichthys molitrix) and grass carp (Ctenopharyngodon idella). Int. J. Agric. Biol., 13, 210-214.

Bahnasawy, M. H., El-Ghobashy, A., \& Abdel-Hakim, N. F. (2009). Culture of the Nile tilapia (Oreochromis niloticus) in a recirculating water system using different protein levels. Egyptian Journal of Aquatic Biology and Fisheries, 13(2), 1-15.

https://doi.org/10.21608/ejabf.2009.2029

Balkhande, J. V. (2019). Cage culture of Oreochromis Mossambicus (Tilapia) in back water 
of river Godavari, Nanded, Maharashtra India. MOJ Ecology and Environmental Sciences, 4(3), 100-105. https://doi.org/10.15406/mojes.2019.04.00140

Baroiller, J. F., \& Borel, F. (1997). Growth/reproduction interactions in Oreochromis niloticus. Proceedings of the Fourth International Symposium on Tilapia in Aquaculture, Florida, USA. p. 272.

Beveridge, M. C. (1984). Cage and pen fish farming. Carrying capacity model and environmental impacts. FAO Fisheries technical paper 255. FAO Rome. p.131.

Beveridge, M. C. M. (1996). Cage aquaculture. Second Edition. Oxford: Fishing News Books. p. 346.

Boyd, C. E. (1998). Water quality for pond aquaculture. Research and Development Series No.43. International center for Aquaculture and Aquatic Environments, Alabama Agricultural Experiment Station, Auburn University, Alabama, 1-7.

Buamah, T. F., \& Singsen, E. P. (1975). Studies on the Protein Efficiency Ratio Method for Evaluation of Poultry Feed Supplements. Modifications associated with choice of dietary protein level for assay. The Journal of Nutrition, 105(6), 688-700.

https://doi.org/10.1093/jn/105.6.688

Bwanika, G. N., Murie, D. J., \& Chapman, L. J. (2007). Comparative age and growth of Nile tilapia (Oreochromis niloticus L.) in lakes Nabugabo and Wamala, Uganda. Hydrobiologia. 589. 287-301. https://doi.org/10.1007/s10750-007-0746-y

Care, (2000). Successful Cage Aquaculture-Low input cage culture in Bangladesh. Care Bangladesh, 3-28.

Caulton, M. S. (1982). Feeding, metabolism and growth of tilapias- some quantitative considerations. In: Pullin R.S.V. and Lowe-McConnell R.H. (eds), The Biology and Culture of Tilapia (pp. 157-184). ICLARM, Manila, the Philippines.

Cavailles, M., Konan, K., \& Doudet, T. (1981). Essai d'élevage de poissons en cage flottante en eaux continentales. C.T.F.T., Division de Recherches en Pisciculture, Bouaké, Côte d'Ivoire. p. 28.

Chakraborty, S. B., \& Banerjee, S. (2012). Comparative growth performance of mixed-sex and monosex Nile tilapia at various stocking densities during cage culture. Recent Research in Science and Technology, 4, 46-50.

Chakraborty, S. B., Mazumdar, D., Chatterji, U., \& Banerjee, S. (2011). Growth of mixed-sex and mono-sex Nile Tilapia in different culture systems. Turkish Journal of Fisheries and Aquatic Science, 11, 131-138. https://doi.org/10.4194/trjfas.2011.0117

Coche, A. G. (1978). Revue des pratiques d'élevage de poissons en cage dans les eaux continentales. Aquaculture, 13, 157-189. https://doi.org/10.1016/0044-8486(78)90109-6

Conover, D. O. (1992). Seasonality and scheduling of life history at different lattitudes. Journal of Fish Biology, 41, 161-178. https://doi.org/10.1111/j.1095-8649.1992.tb03876.x 
Dagne, A., Degefu, F., \& Lakew, A. (2013): Comparative growth performance of mono-sex and mixed-sex Nile tilapia (Oreochromis niloticus L.) in pond culture system at Sebeta, Ethiopia. International Journal of Aquaculture, 3, 30-34.

Dan, N. C., \& Little, D. C. (2000). The culture performance of monosex and mixed-sex new-season and overwintered fry in three strains of Nile tilapia (Oreochromis niloticus) in northern Vietnam. Aquaculture, 184, 221-231.

https://doi.org/10.1016/S0044-8486(99)00329-4

Davies, O. A., Inko-Tariah, M. B., \& Amachree, D. (2006). Growth response and survival of Heterobranchus longifilis fingerlings fed at different feeding frequencies. African Journal of Biotechnology, 5, 778-787.

De Merona, B., Hecht, T. \& Moreau, J. (1988). Croissance des poissons d'eau douce africains. In C. Lévêque, M. N. Bruton \& G. W. Ssentongo (eds), Biologie et Ecologie des Poissons d'Eau Douce Africains (pp. 191-219). Travaux et Documents de l'ORSTOM.

de Oliveira, E. G., Pinheiro, A. B., de Oliveira, V. Q., da Silva Júnior A. R. M., de Moraes, M. G., Rocha, I. R. C. B., de Sousa, R. R. \& Costa F. H. F. (2012). Effects of stocking density on the performance of juvenile pirarucu (Arapaima gigas) in cages. Aquaculture, 370-371, 96-101. https://doi.org/10.1016/j.aquaculture.2012.09.027

Dey, M. M., \& Gupta, M. V. (2000). Socioeconomics of disseminating genetically improved Nile tilapia in Asia: an introduction. Aquaculture Economics and Management, 4, 5-11. https://doi.org/10.1080/13657300009380257

Diana, J. S., Lin, C. K., \& Schneeberger, P. J. (1991). Relationships among nutrient inputs, water nutrient concentrations, primary production, and yield of Oreochromis niloticus in ponds. Aquaculture, 92, 323-341. https://doi.org/10.1016/0044-8486(91)90038-9

Ellis, T., North, B., Scott, A. P., Bromage, N. R., Porter, M., \& Gadd, D. (2002). The relationships between stocking density and welfare in farmed rainbow trout. Journal of Fish Biology, 61, 493-531. https://doi.org/10.1111/j.1095-8649.2002.tb00893.x

Eng, C. T., \& Tech, E. (2002). History of cage culture. In P. T. K. Woo (Eds), Disease and disorders of finfish in cage culture, 138. CABI publishing.

Essa, M. A. (1996). The effect of fish density and feeding frequency on both O. niloticus and Mugil cephalus fish reared as mixed culture on floating eagres. Bull. Nat, Inst. Oceanogr, and Fish. ARE, 22, 181-197.

Ezenwaji, B. I. O., \& Ikusemiju, K. (1981). Age and growth determinations in the catfish Chrysichthys nigrodigiralus (Lacépède) by use of the dorsal spine. Journal of Fish Biology. 19, 345-351. https://doi.org/10.1111/j.1095-8649.1981.tb05837.x

Fermon, Y. (2011). La pisciculture de subsistance en étangs en Afrique : manuel technique. Action contre la faim. ACF-International Network, Paris, 276.

Fitzisimmons, K. (2004). Development of new products and markets for the global tilapia 
trade. In R. Bolivar, G. Mair and K. Fitzsimmons (Eds.), Proceeding of the $6^{\text {th }}$ International Symposium on Tilapia in Aquaculture (pp. 624-633). Manila. Philippines.

Fontaine, P., \& Le Bail, P. Y. (2004). Domestication et croissance chez les poissons. INRA Prod. Anim., 17(3), 217-225.

Garcia, J. A., \& Villarroel, M. (2009). Effect of feed type and feeding frequency on macrophage functions in tilapia (Oreochromis niloticus). Fish Shellfish immune, 27(2), 325-329. https://doi.org/10.1016/j.fsi.2009.05.018

Ghozlan, A. A., Zaki, M. M., Gaber, M. M., \& Nour, A. (2018). Effect of different water sources on survival rate (\%), growth performance, feed utilization, fish yield, and economic evaluation on Nile tilapia (Oreochromis niloticus) monosex reared in earthen ponds. Oceanogr, Fish Open Access J., 6(1), 1-7. https://doi.org/10.19080/OFOAJ.2018.05.555676

Githukia, C. M., Ogello, E. O., Kembenya, E. M., Achieng, A. O., Obiero, K. O., \& Munguti, J. M. (2015). Comparative growth performance of male monosex and mixed sex Nile tilapia (Oreochromis niloticus L.) reared in earthen ponds. Croatian Journal of Fisheries, 73, 20-25. https://doi.org/10.14798/73.1.788

Gupta, M. V., \& Acosta, B. O. (2004). A review of global tilapia farming practices. Aquaculture Asia Magazine, 9, 7-12.

Hengsawat, K., Ward, F. J., \& Jaruratjamorn, P. (1997). The effect of stocking density on yield, growth and mortality of African catfish (Clarias gariepinus Burchell 1822) cultured in cages. Aquaculture, 152, 67-76. https://doi.org/10.1016/S0044-8486(97)00008-2

Hepher, B., \& Pruginin, Y. (1981). Commercial fish farming. Wiley-Interscience Publication, New York. p. 261.

Kebede, A. A. (2011). Effect of feed quality on growth performance and water quality in cage culture system for production of Nile tilapia [Oreochromis niloticus, (Linnaeus, 1758)] in Lake Hora-Arsedi, Ethiopia. Addis Ababa University, School of graduate studies, Faculty of Life Sciences. Thesis presented in partial fulfillment of the requirement for the Degree of Master of Science in Biology, Ethiopia. p. 87.

Kestemont, P., Jourdan, S., Houbart, M., Mélard, C., Paspatis, M., Fontaine, P., Cuvier-Peres, A., Kentouri, M., \& Baras, E. (2003). Size heterogeneity, cannibalism and competition in cultured predatory fish larvae: biotic and abiotic influences. Aquaculture, 227, 333-356. https://doi.org/10.1016/S0044-8486(03)00513-1

Khattab, Y. A. E., Ahmad, M. H., Shalaby, A. M. E., \& Abdel-Tawwab, M. (2000). Response of Nile tilapia (Oreochromis niloticus L.) from different locations to different dietary protein levels. Egyptian Journal of Aquatic Biology \& Fisheries, 4(4), 295-311.

Lazard, J. (2007). Aquaculture et espèces introduites: Exemple de la domestication ex situ des tilapias. Cahiers Agricultures, 16(2), 123-124. https://doi.org/10.1684/agr.2007.0085

Lazard, J. (2009). La pisciculture des tilapias. Cahiers Agricultures, 18(2-3). 393-401. 
https://doi.org/10.1684/agr.2009.0305

Lazard, J., \& Legendre, M. (1994). La pisciculture africaine: enjeux et problèmes de recherche. Synthèse. Cahiers Agricultures, 3, 83-92.

Leatherland, J. F., \& Cho, C. Y. (1985). Effect of rearing density on thyroid and internal gland activity and plasma hepatic metabolite levels in rainbow trout, Salmo gairdneri, Richardson, J. Fish. Biol., 27, 583-592. https://doi.org/10.1111/j.1095-8649.1985.tb03203.x

Legros, D. (1995). Guide technique pour l'élevage du tilapia. CDI, Bruxelles, 1ère édition. p. 45.

Little, D. C., Bhujel, R. C., \& Pham, T. A. (2003). Advanced nursing of mixed-sex and mono-sex tilapia (Oreochromis niloticus) fry, and its impact on subsequent growth in fertilized ponds. Aquaculture, 221, 265-276. https://doi.org/10.1016/S0044-8486(03)00008-5

Lovell, T. (1989). Nutrition and feeding of fish. An AVI Book- Van Nostrand Reinhold, New York, NY, USA. p. 260. https://doi.org/10.1007/978-1-4757-1174-5

Macintosh, D. J., Varghese, T. J., \& Satyanarayana, G. P. (1985). Hormonal sex reversal of wild spawned tilapia in India. Journal of Fish Biology, 26, 87-94.

https://doi.org/10.1111/j.1095-8649.1985.tb04245.x

Mair, G. C., Abucay, J. S., Beardmore, J. A., \& Skibinski, D. O. F. (1995). Growth performance trials of genetically male tilapia (GMT) derived from YY-males in Oreochromis niloticus L.: On station comparisons with mixed sex and sex reversed male populations. Aquaculture, 137, 313-322. https://doi.org/10.1016/0044-8486(95)01110-2

McGinty, A., \& Rakocy, J. (2005). Cage culture. Southern Regional Agricultural Center Extension. Service. USA, 4.

Micha, J. C. (1973). Etude des populations piscicoles de l'Oubangui et tentatives de sélection et d'adaptation de quelques espèces à l'étang de pisciculture ED.C.T.F.T., Paris. p. 110.

Mihelakakis, A., Tsolkas, C., \& Yoshimatsu, T. (2002). Optimization of feeding rate for hatchery produced juvenile gilthead sea bream Sparus aurata. Journal of World Aquaculture Society, 33, 169-175. https://doi.org/10.1111/j.1749-7345.2002.tb00491.x

Mires, D. (1995). The tilapias. In C. E. Nash and A. J. Novotony (Eds.), Production of Aquatic Animals: Fishes (pp.133-152). Elsevier, New York.

Moniruzzaman, M., Uddin, K. B., Basak, S., Mahmud, Y., Zaher, M., \& Bai, S. C. (2015). Effects of Stocking Density on Growth, Body Composition, Yield and Economic Returns of Monosex Tilapia (Oreochromis niloticus L.) under Cage Culture System in Kaptai Lake of Bangladesh. Journal of Aquaculture Research and Development, 6(8), 1-7.

https://doi.org/10.4172/2155-9546.1000357

Moraes, A. M., Seiffert, W. Q., Tavares, F., \& Fracalossi, D. M. (2009). Desempenho zootécnico de tilápia do Nilo, Oreochromis niloticus, em tanques-rede, com diferentes rações comerciais. Revista Ciência Agronômica, 40, 388-395. 
Morgan, P. R. (1972). Causes of mortality in the endemic Tilapia of Lake Chilwa (Malawi). Hydrobiologia, 40, 101-119. https://doi.org/10.1007/BF00123596

Mugo-Bundi, J., Oyoo-Okoth, E., Ngugi, C. C., Manguya-Lusega, D., Rasowo, J., \& Chepkirui, B. V. (2013). Utilization of Caridina nilotica (Roux) meal as a protein ingredient in feeds for Nile tilapia (Oreochromis niloticus). Aquaculture Resources, 2, 1-12. https://doi.org/10.1111/are.12181

Ng, W. K., Lu, K. S., Hashim, R., \& Ali, A. (2000). Effects of feeding rate on growth, feed utilization and body composition of tropical bagrid catfish. Aquaculture International, 8, 19-29. https://doi.org/10.1023/A:1009216831360

Nguyen, N. H., Khaw, H. L., Ponzoni, R. W., Hamzah, A., \& Kamaruzzaman, N. (2007). Can sexual dimorphism and body shape be altered in Nile tilapia by genetic means? Aquaculture. 272. S36-S48. https://doi.org/10.1016/j.aquaculture.2007.08.013

Ouattara, N. I., Teugels, G. G., N'Douba, V., \& Philippart, J. C. (2003). Aquaculture potential of the black-chinned tilapia, Sarotherodon melanotheron (Cichlidae). Comparative study of the effect of stocking density on growth performance of landlocked and natural population under cage culture conditions in Lake Ayame (Côte d'Ivoire). Aquaculture Research, 34, 1223-1229. https://doi.org/10.1046/j.1365-2109.2003.00921.x

Panfili, J., De Pontual, H., Troadec, H., \& Wright, P. J. (2002). Manuel de Sclérochronologie des Poissons. IFREMER/IRD. p. 464. https://doi.org/10.4000/books.irdeditions.20901

Pauly, D. (1983). Some simple methods for the assessment of tropical fish stocks. FAO Fisheries Technical Paper No. 234. FAO, Rome.

Pillay, T. V. R. (1990). Aquaculture: principles and practices. Fishing News Book. Blackwell Scientific Publications, Ltd., Oxford, UK. p. 575.

Ponzoni, R. W., Hamzah, A., Saadiah, T., \& Kamaruzzaman, N. (2005). Genetic parameters and response to selection for live weight in the GIFT strain of Nile tilapia (Oreochromis niloticus). Aquaculture. 247. 203-210. https://doi.org/10.1016/j.aquaculture.2005.02.020

Rakocy, J. E. \& McGinty A. S. (1989). Pond culture of tilapia. Southern Regional Aquaculture Center (SRAC) publication, 280, 1-4.

Ricker, W. E. (1973). Linear regression in fisheries research. Journal of the Fisheries Research Board of Canada, 30, 409-434. https://doi.org/10.1139/f73-072

Ridha, M. T. (2011). Evaluation of monosex culture of GIFT and non-improved strains of Nile tilapia Oreochromis niloticus in recirculating tanks. International Aquatic Resources, 3, 189-195.

Ross, L. G. (2000). Environmental physiology and energetics. In M. C. M. Beveridge and B. J. McAndrew (eds.), Tilapias: Biology and Exploitation (pp.89-128). Fish and Fisheries Series 25, Kluwer Academic Publishers, Dordrecht, The Netherlands.

https://doi.org/10.1007/978-94-011-4008-9_4 
Sarig, S. (1969). Winter storage of tilapia. FAO Fish Culture Bulletin, 2, 8-9.

Shugunan, V. V. (1997). Fisheries management of small water bodies in seven countries in Africa, Asia and Latin America. FAO Fisheries Circular No. 933, Rome, FAO. p.149.

Silva, T. S. D. C., dos Santos L. D., da Silva, L. C., Michelato, M., Furuya, V. R. B., \& Furuya, W. M. (2015). Length-weight relationship and prediction equations of body composition for growing-finishing cage-farmed Nile tilapia. Revista Brasileira Zootecnia, 44(4), 133-137. https://doi.org/10.1590/S1806-92902015000400001

Slawski, H., Adem, H., Tressel, R. P., Wysujack, K., Kotzamanis, Y., \& Schulz, C. (2011). Austausch von Fischmehl durch Rapsproteinkonzentrat in Futtermitteln für Steinbutt (Psetta maxima L). Züchtungskunde, 83, 451-460.

Smith, E. S., \& Phelps, R. P. (2001). Impact of feed storage conditions on growth and efficacy of sex reversal of Nile tilapia. North American Journal of Aquaculture, 63, 242-245. https://doi.org/10.1577/1548-8454(2001)063<0242:IOFSCO>2.0.CO;2

Stiassny, M. L. J., Teugels, G. G., \& Hopkins, C. D. (2007). Poissons d'eaux douces et saumâtres de basse Guinée, ouest de l'Afrique centrale, Vol. I. p. 805.

Symons, P. E. K. (1971). Behavioural adjustment of population density to available food by juvenile Atlantic salmon. Journal of Animal Ecology, 40, 569-587.

https://doi.org/10.2307/3438

Thirupathaiah, M., Samatha, Ch. \& Sammaiah, C. (2012). Analysis of water quality using physico-chemical parameters in lower manair reservoir of Karimnagar district, Andhra Pradesh. International Journal of Environmental Sciences, 3(1), 172-180.

Toguyeni, A., Fauconneau, B., Boujard, T., Fostier, A., Kuhn, R. E., Mol, K. A., \& Baroiller J. F. (1997a). Feeding behaviour and food utilisation in tilapia, Oreochromis niloticus: Effect of sex ratio and relationship with the endocrine status. Physiology and Behavior, 62(2), 273-279. https://doi.org/10.1016/S0031-9384(97)00114-5

Toguyeni, A., Fauconneau, B., Fostier, A., Abucay, A., Mair, G., \& Baroiller, J. F. (2002). Influence of sexual phenotype and genotype, and sex ratio on growth performances in tilapia, Oreochromis niloticus. Aquaculture, 207, 49-261.

https://doi.org/10.1016/S0044-8486(01)00747-5

Wagdy, K. B. K., Wafaa, S. H., Mohamed-Assem, S. M., Hossam, H. A., \& Eman, A. Z. (2011). Assessment the impact of $17 \alpha$-methyltestosterone hormone on growth, hormone concentration, molecular and histopathological changes in muscles and testis of Nile tilapia; Oreochromis niloticus. Life Science Journal, 8(3), 329-343.

Weatherley, A. H., \& Gill, H. S. (1987). The biology of fish growth. Academic Press, London.

Wocher, H., Harsányi, A., \& Schwarz, F. J. (2011). Husbandry conditions in burbot (Lota lota L.): impact of shelter availability and stocking density on growth and behaviour. Aquaculture, 315, 340-347. https://doi.org/10.1016/j.aquaculture.2011.01.051 


\section{Macrothink}

Yager, T. K., \& Summerfelt, R. C. (1993). Effects of fish size and feeding frequency on metabolism of juvenile walleye. Aquacultural Engineering, 13, 257-282.

https://doi.org/10.1016/0144-8609(94)90015-9

\section{Copyright Disclaimer}

Copyright for this article is retained by the author(s), with first publication rights granted to the journal.

This is an open-access article distributed under the terms and conditions of the Creative Commons Attribution license (http://creativecommons.org/licenses/by/3.0/). 